\title{
PENGARUH KOMPENSASI, MOTIVASI DAN KARAKTERISTIK PEKERJAAN TERHADAP KEPUASAN KERJA PEGAWAI PT. JAYA METAL
}

\author{
Lili Supriyadi \\ UIN Syarif Hidayatullah Jakarta
}

\begin{abstract}
The Influence of Compensation, Motivation, and Work Characteristics on Work Satisfaction on PT Jaya Metal. The purposes of this research are to determine the influence of compensation, motivation, and work characteristics on Work Satisfaction. The analysis method used in this research was Pearson's correlation analysis and multiple regression analysis with using three predictors. Based on the research, can be concluded as follows there is a significant positive effect of compensation to Work Satisfaction in PT Jaya Metal Jakarta. There is a significant positive effect of motivation on Work Satisfaction. Also, there is a significant positive effect of Work Characteristics on Work Satisfaction. Thus, the overall results of this analysis support the hypothesis that there were significant influences of compensation, motivation, and work characteristics on work satisfaction.
\end{abstract}

Keywords: compensation, motivation, work characteristics, work satisfaction, regression

\begin{abstract}
Abstrak. Pengaruh Kompensasi, Motivasi, dan Karakteristik Pekerjaan Terhadap Kepuasan Kerja Pegawai PT Jaya Metal. Tujuan dari penelitian ini adalah untuk menentukan pengaruh kompensasi motivasi, dan karakteristik pekerjaan terhadap kepuasan kerja. Metode analisis yang dipergunakan dalam penelitian ini adalah analisis korelasi Pearson dan regresi berganda menggunakan tiga variabel predictor. Hasil yang didapat dari penelitian ini ialah terdapat pengaruh yang positif dan signifikan antara kompensasi dengan kepuasan kerja di PT Jaya Metal Jakarta. Kemudian, terdapat pula pengaruh yang positif dan signifikan antara motivasi dengan kepuasan kerja. Serta, terdapat pengaruh yang positif dan signifikan antara karakteristik pekerjaan terhadap kepuasan kerja. Sehingga secara umum hasil yang didapat mendukung hipotesis bahwa terdapat pengaruh antara kompensasi, motivasi, dan karakteristik pekerjaan terhadap kepuasan kerja.
\end{abstract}

Kata Kunci: kompensasi, motivasi, karakteristik kerja, kepuasan kerja, regresi 


\section{PENDAHULUAN}

Kualitas Sumber Daya Manusia sebagai tenaga kerja merupakan modal dasar dalam masa pembangunan. Tenaga kerja yang berkualitas akan menghasilkan suatu hasil kerja yang optimal sesuai dengan target kerjanya. Manusia sebagai tenaga kerja atau pegawai merupakan sumber daya yang sangat penting bagi perusahaan, karena mereka mempunyai bakat, tenaga dan kreativitas yang sangat dibutuhkan oleh perusahaan untuk mencapai tujuannya. Sebaliknya sumber daya manusia juga mempunyai berbagai macam kebutuhan yang ingin dipenuhinya. Keinginan para pegawai untuk memenuhi kebutuhan inilah yang dapat memotivasi seseorang untuk melakukan sesuatu termasuk untuk melakukan aktifitas pekerjaan atau bekerja, Pemberian kompensasi sangat penting bagi pegawai, karena besar kecilnya kompensasi merupakan ukuran terhadap prestasi kerja pegawai, maka apabila sistem kompensasi yang diberikan perusahaan cukup adil untuk pegawai, akan mendorong pegawai untuk lebih baik dalam melakukan pekerjaannya dan lebih bertanggung jawab atas masing-masing tugas yang diberikan perusahaan. Tujuan kompensasi dilakukan perusahaan antara lain untuk menghargai prestasi pegawai, menjamin keadilan diantara pegawai, mempertahankan pegawai, memperoleh pegawai yang lebih bermutu, dan sistem kompensasi haruslah dapat memotivasi para pegawai. Oleh karena itu, kompensasi merupakan faktor yang penting untuk dapat bekerja lebih produktif dan berkualitas, apalagi jika ditunjang oleh latar belakang pendidikan, keahlian dan pengalaman kerja sesuai dengan karakteristik pekerjaan tersebut, maka dengan sendirinya pegawai akan mendapatkan kepuasan kerja.

Motivasi adalah suatu faktor yang mendorong seseorang untuk melakukan suatu aktivitas tertentu, oleh karena itu motivasi sering kali diartikan pula sebagai faktor pendorong perilaku seseorang. Setiap aktivitas yang dilakukan seseorang pasti memiliki sesuatu faktor yang mendorong aktivitas tersebut. Oleh karena itu, faktor pendorong dari seseorang untuk melakukan suatu aktivitas tertentu pada umumnya adalah kebutuhan serta keinginan orang tersebut. Kinerja perusahaan dapat dinilai dari motivasi kerja pegawainya. Motivasi kerja yang salah satunya disebabkan oleh pemberian 
kompensasi yang sesuai dapat terlihat dari kinerja pegawai tersebut dalam menjalankan tugasnya. Jika kompensasi lebih diperhatikan oleh perusahaan maka diharapkan keahlian yang dimiliki pegawai dan motivasi kerja dapat meningkat sehingga kepuasan kerja pegawai juga meningkat.

Faktor-faktor yang ada dalam muatan pekerjaan tersebut dikenal dengan nama karakteristik pekerjaan (job characteristics) atau ada juga yang menyebut sebagai dimensi inti pekerjaan (core job dimensions). Karakteristikkarakteristik pekerjaan tersebut diidentifikasi sebagai atribut tugas yang memiliki tingkat kepentingan khusus bagi perancangan jabatan dan karakteristik pekerjaan yang sesuai dapat membuat seseorang untuk mendapat kepuasan kerja. Kepuasan kerja merupakan sesuatu yang menyenangkan atau hasil sisi emosional positif dari penilaian atau pengalaman kerja. Kepuasan kerja merujuk pada sikap dan perilaku umum individual terhadap pekerjaannya, dan merupakan kekuatan untuk melakukan pekerjaan dengan baik.

Kompensasi adalah segala bentuk pembayaran atau imbalan yang diberikan kepada pegawai oleh perusahan atau sebagai balas jasa atas kontribusi mereka kepada perusahaan berupa finansial seperti gaji, upah, bonus dan tunjangan-tunjangan lainnya. Sedangkan kompensasi non-finansial adalah kompensasi yang diterima pegawai dalam bentuk promosi jabatan dan penghargan lainnya. Agar dalam pelaksanaannya program pemberian kompensasi dapat berjalan secara efektif, maka program kompensasi tersebut harus menerapakan azas-azas pemberian kompensasi yaitu pertama, azas adil; artinya besarnya kompensasi yang diberikan kepada pegawai harus disesuaikan dengan prestasi kerja, jenis pekerjaan, resiko pekerjaan, tanggung jawab, jabatan pekerjaan dan memenuhi persyaratan internal. Kedua, azas layak dan wajar; artinya kompensasi yang diberikan kepada pegawai harus dapat memenuhi kebutuhannya pada tingkat normatif yang ideal.

Selain itu beberapa hal yang perlu dilakukan dalam usaha pengembangan suatu sistem kompensasi, antara lain melakukan analisis pekerjaan, melakukan penilaian terhadap pekerjaan dikaitkan dengan keadilan internal. Menurut Singodimedjo dalam Sutrisno (2009), kompensasi adalah 
semua balas jasa yang diterima seorang karyawan dari perusahaannya sebagai akibat dari jasa atau tenaga yang telah diberikannya pada perusahaan tersebut. Kompensasi menurut Tohardi dalam Sutrisno (2009), bahwa kompensasi dihitung berdasarkan evaluasi pekerjaan, perhitungan kompensasi berdasarkan evaluasi pekerjaan tersebut dimaksudkan untuk mendapatkan pemberian kompensasi yang mendekati kelayakan (worth) dan keadilan (equity).

Menurut Panggabean dalam Sutrisno (2009), kompensasi dapat dibedakan menjadi dua, yaitu: Pertama, kompensasi Langsung adalah kompensasi yang langsung dirasakan olah penerimanya, yakni berupa gaji, tunjangan, insentif merupakan hak karyawan dan kewajiban perusahaan untuk membayarnya. Kedua, kompensasi Tidak Langsung adalah kompensasi yang tidak dapat dirasakan secara langsung oleh karyawan, yakni benefit dan services (tunjangan pelayanan). Benefit dan services adalah kompensasi tambahan (financial atau non financial) yang diberikan berdasarkan kebijaksanaan perusahaan terhadap semua karyawan dalam usaha meningkatkan kesejahteraan mereka. Seperti tunjangan hari raya, uang pensiun, pakaian dinas, olah raga dan darma wisata (family gathering). Mawar (2007) mencoba menguji pengaruh kompensasi, pelatihan, kepemimpinan, dan lingkungan kerja Terhadap Kinerja Pegawai di PT Askes (Persero) Kantor Cabang Denpasar secara statistik dan menjelaskan secara deskriktif maupun kuantitatif. Peneliti mengungkapkan betapa pentingnya mengelola Sumber Daya manusia untuk menunjukkan bahwa sukses atau tidaknya sebuah organisasi sangat tergantung pada tenaga kerja yang dimiliki oleh organisasi tersebut. Hasil penelitiannya menunjukkan bahwa kompensasi, pelatihan, kepemimpinan dan lingkungan kerja secara simultan mempengaruhi kinerja pegawai PT Askes (Persero) Kantor Cabang Denpasar.

Tujuan pemberian kompensasi kepada karyawan antara lain menjamin sumber nafkah karyawan beserta keluarganya, meningkatkan prestasi kerja, meningkatkan harga diri para karyawan, mempererat hubungan kerja antar karyawan, mencegah karyawan meninggalkan perusahaan, meningkatkan disiplin kerja, efisiensi tenaga karyawan yang potensial, perusahaan dapat 
bersaing dengan tenaga kerja di pasar, mempermudah perusahaan mencapai tujuan, melaksanakan peraturan perundang-undangan yang berlaku dan perusahaan dapat menyediakan fasilitas teknologi baru. Puspanegara (2003) dalam penelitian yang berjudul Pengaruh Motivasi, Kompensasi, dan Kemampuan terhadap Kinerja Pegawai Negeri Sipil (PNS) di Lingkungan Dinas Pertanian, Peternakan, dan Perikanan Kabupaten Lampung Utara. Penelitian ini dilaksanakan untuk mengetahui pengaruh motivasi, kompensasi, dan kemampuan terhadap kinerja pegawai negeri sipil di lingkungan Dinas Pertanian, Pertanakan dan Perikanan Kabupaten Lampung Utara. Teknik analisis yang digunakan yaitu analisis deskriptif kuantitatif, sedangkan pengujian hipotesis menggunakan analisis regresi berganda.

Motivasi adalah serangkaian sikap dan nilai-nilai yang mempengaruhi individu untuk mencapai hal yang spesifik sesuai dengan tujuan individu. Sikap dan nilai tersebut merupakan suatu yang invisible yang memberikan kekuatan untuk mendorong individu bertingkah laku dalam mencapai tujuan. Dorongan tersebut terdiri dari dua komponen, yaitu arah perilaku (kerja untuk mencapai tujuan) dan kekuatan perilaku (seberapa kuat usaha individu dalam bekerja). Motivasi meliputi perasaan unik, pikiran dan pengalaman masa lalu yang merupakan bagian dari hubungan internal dan eksternal perusahaan. Selain itu motivasi dapat pula diartikan sebagai dorongan individu untuk melakukan tindakan karena mereka ingin melakukannya. Apabila individu termotivasi, mereka akan membuat pilihan yang positif untuk melakukan sesuatu, karena dapat memuaskan keinginan mereka (Rivai, 2004).

Menurut Malthis (2006), motivasi adalah keinginan dalam diri seseorang yang menyebabkan orang tersebut bertindak. Biasanya orang bertindak karena suatu alasan untuk mencapai tujuan. Memahami motivasi sangatlah penting karena kinerja, reaksi terhadap kompensasi dan persoalan sumber daya manusia yang lain dipengaruhi dan mempengaruhi motivasi. Pendekatan untuk memahami motivasi berbeda-beda, karena teori yang berbeda mengembangkan pandangan dan model mereka sendiri. Teori motivasi manusia yang dikembangkan oleh Maslow dalam Mathis (2006), mengelompokkan kebutuhan manusia menjadi lima kategori yang naik dalam 
urutan tertentu. Sebelum kebutuhan lebih mendasar terpenuhi, seseorang tidak akan berusaha untuk memenuhi kebutuhan yang lebih tinggi. Hierarki yang terkenal terdiri atas kebutuhan fisiologis, kebutuhan akan keselamatan dan keamanan, kebutuhan akan kebersamaan dan kasih sayang, kebutuhan akan aktualisasi diri. Kebutuhan seseorang merupakan dasar untuk model motivasi. Kebutuhan adalah kekurangan yang dirasakan oleh seseorang pada saat tertentu yang menimbulkan tegangan yang menyebabkan timbulnya keinginan. Pegawai akan berusaha untuk menutupi kekurangannya dengan melakukan suatu aktivitas yang lebih baik dalam melaksanakan pekerjaannya. Dengan melakukan aktivitas yang lebih banyak dan lebih baik diharapkan akan memperoleh hasil yang lebih baik pula sehingga keinginannya dapat terpenuhi. Keinginan yang timbul dalam diri karyawan dapat berasal dari dalam dirinya sendiri maupun berasal dari luar dirinya, baik yang berasal dari lingkungan kerjanya maupun dari luar lingkungan kerjanya.

Membahas masalah karakteristik pekerjaan tidak lepas dari perancangan pekerjaan. Pekerjaan yang baik harus lebih baik dari sekedar sekumpulan tugas yang harus dilakukan sebagaimana yang dihasilkan oleh informasi analisis. Dalam merancang bangun pekerjaan ada tiga hal penting yang harus diperhatikan. Pertama, dalam merancang bangun pekerjaan harus mencerminkan usaha pemenuhan tuntutan lingkungan, organisasional dan keperilakuan terhadap pekerjaan yang dirancang bangun itu, Kedua, mempertimbangkan ketiga tuntutan di atas berarti upaya diarahkan pada pekerjaan yang produktif dan memberikan kepuasan pada prilakunya, meksipun dapat dipastikan bahwa tingkat produktivitas dan kepuasan itu tidak akan sama pada setiap orang. Ketiga, tingkat produktivitas dan kepuasan para pelaksana pekerjaan harus mampu berperan sebagai umpan balik. Model karakteristik pekerjaan (Job Characteristics Model- selanjutnya disingkat JCM), model ini merupakan peningkatan dari konsep pemerkayaan pekerjaan (job enrichment), JCM telah menjadi dasar dari berbagai kajian dan perancangan pekerjaan selama lebih dari dua dekade, dan secara ekstensif selalu ditinjau ulang. Sebagian besar penelitian yang dilakukan, mendukung validitas dari model ini, JCM dikembangkan dengan tujuan untuk mencari sebuah model 
perancangan pekerjaan yang dapat meningkatkan motivasi kerja. Dengan kata lain, untuk mencari tahu dalam kondisi seperti yang bagaimana, motivasi dari diri seseorang dapat muncul. maka seseorang dapat termotivasi, apabila orang tersebut mengalami keadaan psikologis tertentu. Keadaan psikologis itu dinamakan keadaan psikologis kritis (Critical psychological states).

Penghargaan intrinsik diperoleh individu ketika dia belajar (knowledge of result) bahwa dia secara pribadi (experienced responsibility) telah melakukan tugas dengan baik pada tugas yang bermakna baginya (experienced meaningfulness). Penghargaan intrinsik yang didapatkan oleh karyawan tersebut akan menimbulkan motivasi kerja internal, kemudian jika merunut mundur untuk mencari faktor-faktor dalam pekerjaan yang dapat memunculkan kondisi-kondisi tersebut, maka dapat disimpulkan bahwa faktorfaktor dalam pekerjaan yang dapat memunculkan pengalaman akan arti penting dari pekerjaan adalah adanya variasi keterampilan (skill variety), identitas tugas (Task identity), dan nilai penting tugas (Task significance). Hackman \& Oldham (dalam Robbin 2001) menjelaskan bahwa: "Karakteristik peker-jaan merupakan aspek internal dari suatu pekerjaan yang mengacu pada isi dan kondisi dari pekerjaan". Suatu model karakteristik kerja diajukan oleh Hackman \& Oldham (dalam Robbins, 2001) yang mengidentifikasikan lima dimensi inti dari karakteristik kerja meliputi keragaman kecakapan (skill vari-ety), identitas pekerjaan (task identity), keberartian pekerjaan (task signifi-cance), otonomi (otonomy), dan umpan balik dari pekerjaan (feedback from job).

Model karakteristik pekerjaan ini memunculkan motivasi internal akibat adanya suatu pengalaman dan pengha-yatan psikologis pekerja setelah melakukan pekerjaannya. Menurut Maman Kusman (1999) menyatakan bahwa faktor kepuasan kerja merupakan unsur dari kepuasan kerja yakni bersumber pada pekerjaan (Intrinsic factor) serta yang berada di lingkungan kerja pegawai yang bersangkutan (Extrinsic factor) dan bersumber dari proses kerja dan hasil kerja (Satisfaction on the work process and outcome).

Selanjutnya Robbins (2001) berpendapat bahwa kepuasan kerja adalah "A general attitude toward one's job; the difference between the amount of rewards workers receive and the amount they believe they should receive". 
Selanjutnya Robbins (2001) menyatakan bahwa faktor penting yang mendorong kepuasan kerja yaitu kerja yang secara mental menantang, ganjaran yang pantas, kondisi kerja yang mendukug dan rekan kerja yang mendukung. Variabel-variabel kepuasan kerja yang langsung pengaruhnya terhadap kepuasan kerja yaitu : Kompensasi, pekerjaan itu sendiri, kesempatan promosi, kelompok kerja, serta kondisi kerja. Alaydroes (2000) membuktikan bahwa karakteristik pekerjaan ternyata memiliki hubungan yang signifikan dengan iklim organisasi meskipun dalam tingkat yang rendah, artinya karakteristik pekerjaan berperan relatif kecil dalam menumbuhkan iklim organisasi, karena iklim organisasi dibentuk oleh berbagai aspek.

Rongga et.al (2001) membuktikan bahwa "existence of relation which are positive between organizational climate with job satisfaction of employees". adanya hubungan yang positif antara iklim organisasi dengan kepuasan kerja karyawan. Dalam penelitiannya ia menunjukan bahwa kepuasan dalam pekerjaan timbul dari akibat oleh cara yang ditunjukan para manajer dalam memperhatikan dan meminta pendapat serta keikutsertaan bawahannya, sehingga para pekerja merasa bahwa mereka merupakan bagian integral dari organisasinya dan merasa bahwa atasan memperhatikan mereka. Pendekatan terhadap iklim organisasi menggunakan dimensi yang dikembangkan oleh James and Jones, yaitu : Leader facilitation and support; Workgroup cooperation, friendliness and warmth; Conflict and pressure; Organizational planning; Job standards, Dalam karakteristik pekerjaan akan menggunakan model Hackman-Oldham yang menggunakan lima sifat yang melekat pada pekerjaan yang merujuk pada instrumen Job Diagnostik Survey yaitu : Variety of skill, Identity of task, Signifi-cance of task, Autonomy, and Feedback. Adapun yang menjadi dimensi kepuasan kerja adalah Compensation, work it self, promation, work group, and working condition.

Lingkungan kerja dalam suatu perusahaan termasuk salah satu hal yang penting untuk diperhatikan. Meskipun lingkungan kerja tidak melaksanakan proses produksi dalam suatu perusahaan, namun lingkungan kerja mempunyai pengaruh langsung terhadap para karyawan yang melaksanakan proses produksi tersebut. Lingkungan kerja yang memusatkan bagi karyawannya dapat meningkatkan kinerja. Sebaliknya lingkungan kerja yang tidak memadai akan dapat menurunkan kinerja dan akhirnya menurunkan motivasi kerja karyawan. Menurut Lewa dan Subowo (2005) lingkungan kerja didesain sedemikian rupa agar dapat tercipta hubungan kerja yang mengikat pekerja 
dengan lingkungannya. Lingkungan kerja yang baik yaitu apabila karyawan dapat melaksanakan kegiatan secara optimal, sehat, aman dan nyaman. Lingkungan kerja yang kurang baik dapat menuntut tenaga kerja serta waktu yang lebih banyak dan tidak mendukung diperolehnya rencangan sistem kerja yang efisien.

Lingkungan kerja merupakan segala sesuatu yang ada di sekitar karyawan pada saat bekerja, yang dapat mempengaruhi dirinya dan pekerjaannya saat bekerja. Pertimbangan unsur lingkungan berkaitan dengan aspek-aspek kemampuan, kesediaan pegawai dan harapan-harapan masyarakat. Kemampuan dari pegawai akan menentukan tingkat spesialisasi pekerjaan yang tepat. Seorang pegawai dengan kemampuan yang rendah lebih efektif dengan spesialisasi yang lebih tinggi dibandingkan dengan pegawai yang mempunyai kemampuan lebih tinggi. Ketersediaan pegawai juga akan menentukan tingkat spesialisasi yang akan diterapakan.

Rancang bangun pekerjaan tidak boleh sematamata dikaitkan hanya dengan efisiensi kerja saja, meskipun tidak dapat dipungkiri bahwa orientasi efisiensi, efektivitas dan produktivitas sangat penting dalam sutu organisasi. Unsur keperilakuan berkaitan dengan beberapa karakteristik dan pekerjaan yang dapat memenuhi keinginan atau motif seseorang dalam pelaksanan suatu pekerjaan, yaitu otonomi dalam pelaksanaan pekerjaan, variasi tugas, identitas tugas, signifikansi tugas, dan umpan balik.

Kepuasan kerja merupakan sesuatu yang menyenangkan atau hasil sisi emosional positif dari penilaian atau pengalaman kerja. Berbagai defenisi tentang kepuasan kerja telah dibuat oleh para ahli. Diantaranya adalah Siagian menuliskan bahwa "kepuasan kerja merupakan suatu cara pandang seseorang, baik yang bersifat positif maupun bersifat negatif, tentang pekerjaannya" (Siagian, 2000). Dari defenisi tersebut, dapat disimpulkan bahwa kepuasan kerja adalah perasaan positif seseorang terhadap pekerjaannya. Kepuasan kerja merupakan salah satu elemen yang cukup penting dalam organisasi. Hal ini disebabkan kepuasan kerja dapat mempengaruhi perilaku kerja seseorang seperti malas, rajin, produktif, apatis, dan lain-lain. sikap puas atau tidak puas pegawai dapat diukur dari sejauh mana perusahan atau organisasi dapat 
memenuhi kebutuhan pegawai. Bila terjadi keserasian antara kebutuhan pegawai dengan apa yang diberikan perusahan, maka tingkat kepuasan yang dirasakan pegawai akan tinggi, dan sebaiknya. Ketidakpuasan kerja sering tercermin dari prestasi kerja yang akan rendah, tingkat kemangkiran yang tinggi, seringnya terjadi kecelakaan kerja,dan bahkan pemogokan kerja yang pada akhirnya akan sangat merugikan perusahan.

Kepuasan kerja pegawai dipengaruhi oleh banyak factor, menurut teori kepuasan kerja yang dikemukakan oleh Frederick Herzberg dalam Luthans (2006) mengemukakan Teori Dua Faktor yaitu faktor motivator dan faktor hygiene. Faktor motivator berhubungan dengan aspek-aspek yang terkandung dalam pekerjaan itu sendiri (job content) atau disebut juga sebagai aspek intrinsik dalam pekerjaan sedangkan faktor hygiene yaitu faktor yang berada di sekitar pelaksanaan pekerjaan, berhubungan dengan job context atau aspek ekstrinsik pekerja. Proses untuk membuat pegawai merasakan puas dalam bekerja, pihak pimpinan perusahaan harus memastikan bahwa faktor hygiene telah memadai seperti gaji, keamanan dan kondisi kerja aman serta hubungan rekan kerja dan atasan baik. Pimpinan yang menyediakan faktor-faktor hygiene secara memadai belum sepenuh merangsang motivasi karyawan tetapi hanya memastikan karyawan tidak merasakan ketidakpuasan atau berada pada titik nol landasan motivasi. Untuk itu pihak pimpinan harus menyediakan faktor penggerak motivator (intrinsik) kepada karyawan seperti prestasi, pengakuan, tanggung jawab dan pengembangan kesempatan untuk maju. Bila hal ini mendapat perhatian dari perusahaan akan memberikan tingkat kepuasan yang tinggi (Griffin,2006). Dampak kepuasan kerja cenderung terpusat pada kinerja pegawai, tingkat kehadiran, dan tingkat keluar masuknya karyawan (turnover). Organisasi dengan karyawan yang lebih puas cenderung memiliki kinerja dan tingkat kehadiran yang lebih tinggi serta turnover yang lebih rendah dibandingkan dengan organisasi yang memiliki karyawan yang kurang puas (Robbins, 2006)

Untuk mengetahui faktor -faktor yang mempengaruhi kepuasan kerja menurut F. Herzberg dalam Luthans (2006) adalah Two faktor theory (teori dua faktor), menyatakan puas atau tidaknya pegawai bekerja dipengaruhi faktor 
motivator (satisfier) dan faktor hygiene (dissatisfier). Faktor motivator (satisfier) berhubungan dengan aspek- yang terkandung dalam pekerjaan itu sendiri atau job content yang disebut juga sebagai aspek intrinsik dalam pekerjaan. Faktor-faktor yang termasuk dalam faktor motivator adalah keberhasilan melakukan tugas, pengakuan, pekerjaan itu sendiri, tanggung jawab, kemungkinan untuk pengembangan kemajuan. Faktor yang kedua adalah faktor hygiene (dissatisfier) yang berhubungan dengan aspek di sekitar pelaksanaan pekerjaan atau job context yang disebut juga aspek ekstrinsik pekerja, yang terdiri dari kebijaksanaan dan prosedur perusahaan, supervisor, upah/gaji, hubungan dengan rekan kerja, kondisi kerja. Faktor hygiene (Dissatisfier) (X2), Faktor motivator (Satisfier) ( X1 ) dan Kepuasan Kerja (Y)

\section{METODE}

Untuk mempermudah proses penelitian, terlebih dahulu harus diketahui jumlah populasi, dan sampel, serta metode sampling yang akan digunakan dalam proses penelitian. Populasi dalam penelitian ini adalah seluruh pegawai PT. Jaya Metal Jakarta yang berjumlah 84 orang pegawai. Sampel dalam penelitian ini adalah seluruh populasi pegawai PT. Jaya Metal Jakarta karena subjeknya kurang dari 100 (Arikunto, 2006). Teknik pengambilan sampel dalam penelitian ini adalah menggunakan cara sampling jenuh yaitu teknik penentuan sampel bila semua anggota populasi digunakan sebagai sampel (Sugiyono, 2006). Jumlah penyebaran berdasarkan kesediaan pihak PT. Jaya Metal Jakarta dari tiap bagian (divisi). Terdapat 5 divisi, setiap divisi bersedia mengisi 10 kuesioner, jadi sampel dalam penelitian ini adalah 50 orang pegawai.

Sumber data yang digunakan dalam penelitian hanya menggunakan data primer. Data primer dalam penelitian ini diperoleh dengan memberikan angket (kuesioner) yang meliputi angket tentang pola kepemimpinan, motivasi, pengembangan karir, dan kinerja karyawan yang diberikan kepada pegawai yang bertindak sebagai sampel. Metode pengumpulan data yaitu cara-cara yang dapat digunakan untuk mengumpulkan data (Arikunto, 2006).

Variabel yang digunakan dalam penelitian ini terdiri dari dua macam, yaitu variabel dependen (kinerja karyawan) dan variabel independen (motivasi, 
pola kepemimpinan, dan pengembangan karir) diukur dengan kuesioner yang digunakan dalam penelitian Anggara (2007). Kepuasan kerja akan dirasakan ketika setiap kebutuhan jasmani dan kebutuhan rogani dapat terpenuhi, dalam kepuasan kerja terdapat dua istilah yaitu kepuasan kerja intrinsik dan kepuasan kerja ekstrinsik. Kepuasan kerja intrinsik adalah motivator factors yang menunjukkan bahwa penghargaan yang berasal dari dalam diri individual dan dirasakan pada saat melakukan pekerjaan serta tidak dapat dipisahkan dari pekerjaan itu sendiri, penghargaan tersebut berupa pencapaian, pengakuan, pekerjaan itu sendiri, memimpin diri sendiri, dan tanggung jawab yang mengarah pada kepuasan kerja intrinsik, hal ini berkaitan langsung dengan melakukan pekerjaan. Sedangkan kepuasan kerja ekstrinsik serupa dengan hygiene factors yang menunjukkan bahwa penghargaan yang berasal dari luar dan tidak menimbulkan kepuasan pada saat individual melakukan pekerjaan. Penghargaan itu berupa penghargaan sosial seperti sikap bersahabat, sikap menolong, dukungan rekan kerja, kebijaksanaan supervisor serta penghargaan organisasi seperti upah, kondisi kerja, dan kesempatan promosi. Tujuan penelitian ini adalah menganalisis seberapa besar kompensasi, motivasi, dan karakteristik pekerjaan mampu mempengaruhi kepuasan kerja pegawai. Variabel independent (variabel bebas) dalam penelitian ini yang menjadi variabel independent adalah: Kompensasi, Motivasi Kerja dan Karakteristik Pekerjaan.

Validitas adalah keadaan yang menggambarkan tingkat instrumen yang bersangkutan mampu mengukur apa yang diukur (Arikunto, 2006). Uji validitas instrumen dilakukan untuk mengetahui seberapa jauh instrumen penelitian mampu mencerminkan isi sesuai dengan hal dan sifat yang diukur. Artinya, setiap butir instrumen telah benar-benar menggambarkan keseluruhan isi atau sifat bangun konsep (konstruk teori) yang menjadi dasar penyusunan instrumen. Arikunto (2006) menyatakan bahwa analisis butir dilakukan untuk mengetahui apakah butir dalam instrumen mencerminkan indikator variabel yang dimaksud atau atribut yang hendak diukur. Untuk mengetahui validitas butir tiap angket, skor-skor yang ada pada tiap butir yang dimaksud (X) dikorelasikan dengan skor total (Y). Hasil korelasi ini dikonsultasikan dengan 
tabel nilai korelasi product moment pada taraf signifikansi 5\%. Suatu butir instrument dikatakan valid jika r-hitung > r-tabel. Untuk pengujian ini digunakan rumus korelasi product moment dengan angka kasar sebagaimana yang dikemukakan oleh Arikunto (2006)

Reliabilitas atau keterandalan suatu instrumen sebagai alat ukur dimaksudkan untuk mengetahui sejauh mana kebenaran alat ukur cocok digunakan sebagai alat ukur untuk mengukur sesuatu. Dengan demikian, suatu instrumen yang reliable memberikan pengertian bahwa instrumen itu telah benar-benar memiliki taraf keajegan dalam mengukur apa yang hendak diukur. Untuk uji reliabilitas instrumen digunakan rumus Alpha dari Cronbach. Instrumen dikatakan reliabel jika koefisien Alpha (cronbach alpha) $>60 \%$ $(0,60)$ berdasarkan kriteria Nunnaly (1967) dalam Ghozali (2006).

Dalam penelitian ini ada empat variabel, yakni tiga variabel bebas $(\mathrm{X})$ dan satu variabel terikat (Y). Variabel bebas terdiri atas motivasi, pola kepemimpinan, dan pengembangan karir, sedangkan variabel terikat adalah kinerja karyawan. Untuk menganalisis data ditempuh langkah-langkah berikut ini. Pengujian asumsi klasik ini menggunakan uji normalitas, uji multikolinieritas, dan uji heteroskedastisitas.

Uji normalitas bertujuan untuk menguji apakah dalam model regresi, variabel terikat dan variabel bebas keduanya mempunyai distribusi normal ataukah tidak. Model regresi yang baik adalah yang memiliki distribusi data normal atau mendekati normal. Adapun salah satu cara untuk melihat normalitas yaitu dengan menggunakan metode Kolmogorov-Smirnov, yaitu dengan melihat nilai Zhitung dari Kolmogorov-Smirnov Test pada variabel dependen dibandingkan dengan Ztabel atau dengan cara yang mudah yaitu dengan melihat nilai Asymp. Sig (2-tailed) pada variabel dependen dengan taraf signifikansi 5\% $(0,05)$. Suatu model regresi memiliki distribusi data normal apabila nilai Asymp. Sig (2-tailed) > 0,05 (Ghozali, 2005).

Multikolinearitas adalah adanya suatu hubungan linier yang sempurna (mendekati sempurna) antara beberapa atau semua variabel bebas (Kuncoro, 2003). Menurut Ghozali (2006), jika dari matrik korelasi antar variabel bebas ada korelasi yang sempurna atau cukup tinggi (di atas 0,90), maka hal ini 
merupakan indikasi adanya multikolinearitas, dan sebaliknya. Uji Multikolinearitas bertujuan untuk menguji apakah model regresi ditemukan adanya korelasi antar variabel bebas (independen). Dalam penelitian ini, untuk mendeteksi ada atau tidaknya multikolinearitas di dalam regresi digunakan matrik korelasi variabel-variabel bebas dan melihat nilai Tolerance dan Variance Inflation Factor (VIF) dengan penghitungan bantuan program SPSS for windows.

Heteroskedisitas adalah apabila kesalahan atau residual yang diamati tidak memiliki variabel varian yang konstan. Kondisi heterosedisitas sering terjadi pada data cross section atau data yang diambil dari beberapa responden pada suatu waktu tertentu. Hasil uji heteroskedisitas glejser adalah bahwa apabila nilai thitung pada masing masing variabel $<\mathrm{t}$ tabel atau nilai probabilitas (Asymp.Sig) > 0,05, maka data variabel tidak terjadi heteroskedatisitas (Ghozali, 2006). Teknik analisis statistik yang digunakan adalah regresi linier berganda yang selain untuk mengukur kekuatan hubungan antara dua variabel atau lebih, juga menunjukkan arah hubungan antara variabel dependen dengan variabel independen (Ghozali, 2006). Adapun persamaan matematis yang diajukan dalam model penelitian ini ialah

$$
\mathrm{KK}=\alpha+\beta_{1} \mathrm{Kom}+\beta_{2} \mathrm{Mot}+\beta_{3} \mathrm{KrP}+\varepsilon
$$

Di mana:

$\mathrm{KK}=$ Kepuasan Kerja

Kom = Kompensasi

Mot $=$ Motivasi

$\mathrm{KrP}=$ Karakter Pekerjaan

Selanjutnya untuk memmbuktikan hipotesis dilakukan uji ketepatan model dan uji parameter penduga. Uji F pada dasarnya menunjukkan apakah semua variabel bebas (independen) yang dimasukkan dalam model mempunyai pengaruh secara simultan terhadap variabel terikat (Kuncoro, 2001). Apabila nilai F-hitung > F-tabel, maka semua variabel independen secara serentak dan signifikan mempengaruhi variabel dependen. Menghitung Koefisien Determinasi $\left(\mathrm{R}^{2}\right)$ Uji koefisien determinasi digunakan untuk mengetahui seberapa besar varian dari variabel dependen dapat dijelaskan ileh variabel independen. $\mathrm{R}^{2}$ yang digunakan dalam penelitian ini adalah $\mathrm{R}^{2}$ yang mempertimbangkan jumlah variabel independen dalam suatu model atau 
disebut Adjusted- $R^{2}$ atau $\mathrm{R}^{2}$ yang telah disesuaikan. $\mathrm{R}^{2}$ adalah perbandingan antara variasi dependen (terikat) yang dijelaskan oleh variasi independen (bebas). Semua variabel di luar model diwadahi dalam $\varepsilon$; jika variabel dalam model hanya menjelaskan 0,2, maka berarti sebesar 0,8 ditentukan oleh variabel di luar model. Semakin besar ukuran sampel maka nilai $\mathrm{R}^{2}$ cenderung makin kecil (Setiaji, 2006).

Uji t statistik digunakan untuk menguji apakah variabel independen (X) berpengaruh terhadap variabel dependen (Y). Pengujian ini dilakukan dengan asumsi bahwa variabel-variabel lain adalah 0. Adapun kriteria pengujian apabila Nilai ttabel yang diperoleh dibandingkan dengan nilai thitung. Apabila thitung < t-tabel atau t-hitung > t-tabel, maka Ho ditolak, sehingga dapat disimpulkan bahwa variabel independen berpengaruh terhadap variabel dependen. Untuk mencapai suatu sumber daya manusia yang berkualitas tidaklah lepas dari motivasi seseorang untuk bekerja. Tanpa motivasi yang positif kualitas itu sendiri tidak akan tercapai. Banyak faktor dalam mempengaruhi motivasi seseorang untuk bekerja lebih produktif. Hal utama yang mendapatkan perhatian dari seorang pegawai atau bawahan adalah kepemimpinan yang diberikan dari seorang pemimpin. Tanpa seorang pemimpin yang baik, kontrol terhadap bawahannya akan kurang, sehingga produktivitas pegawai tidaklah akan maksimal. Hal itu sesuai dengan pendapat yang menyatakan bahwa seorang manajer dalam memimpin para bawahannya harus mampu memberikan dorongan, pengarahan, bimbingan, penyuluhan, pengendalian, keteladanan, dan bersikap jujur serta tegas, agar para bawahan mau bekerja sama dan bekerja efektif untuk mewujudkan tujuan yang diinginkan (Hasibuan, 2003). Motivasi kerja tidak hanya berasal kontribusi dari kepemimpinan seorang pemimpin saja, akan tetapi stres kerja yang dialami seorang pekerja juga dapat menurunkan motivasi kerja seseorang.

\section{PEMBAHASAN}

Berdasarkan hasil pengumpulan data dari 45 kuesioner yang disebar, hanya 43 kuesioner yang kembali. Kemudian dari hasil tabulasi data hanya 40 kuesioner yang dapat diolah karena tiga kuesioner rusak atau diisi tidak lengkap (tidak layak dijadikan sampel). 
Hasil pengolahan data dengan deskriptif frekuensi dari unsur jenis kelamin responden menunjukkan bahwa dari seluruhan jumlah responden sebanyak 40 orang didapatkan jumlah responden yang berjenis kelamin lakilaki sebanyak 21 orang $(52,5 \%)$ dan yang berjenis kelamin perempuan sebanyak 19 orang (47,5\%). Usia responden menunjukkan bahwa dari seluruhan jumlah responden sebanyak 40 orang yang berusia 41-50 tahun memiliki persentase yang paling besar yaitu sebesar 42,5\% (17 orang), kemudian diikuti kategori usia > 50 tahun dengan persentase 22,5\% (9 orang), kategori $<30$ tahun dengan persentase 20,0\% (8 orang), dan terakhir adalah responden yang berkategori usia 31-40 tahun sebanyak 6 orang $(15,0 \%)$.

Dari unsur pendidikan terakhir responden menunjukkan bahwa dari seluruhan jumlah responden sebanyak 40 orang pegawai/karyawan diketahui yang memiliki pendidikan terakhir SMA/Sederajat adalah persentase yang paling besar dibandingkan dengan dua kategori lainnya yaitu dengan jumlah responden 19 orang (47,5\%), kemudian diikuti kategori yang berpendidikan terakhir diploma dengan persentase 27,5\% (11 orang), dan terakhir adalah responden yang berpendidikan terakhir S1 sebanyak 10 orang (25,0\%). Hasil menunjukkan mayoritas karyawan yang menjadi responden berpendidikan terakhir SMA/Sederajat.

Unsur masa kerja responden menunjukkan bahwa dari seluruhan jumlah responden sebanyak 40 orang yang memiliki masa kerja > 10 tahun adalah persentase yang paling besar dibandingkan dengan dua kategori lainnya yaitu dengan jumlah responden 29 orang (72,5\%), kemudian diikuti kategori yang memiliki masa kerja 5-10 tahun dengan persentase 15,0\% (6 orang), dan terakhir adalah responden yang memiliki masa kerja $<5$ tahun.

Hasil pengujian Validitas kinerja karyawan, Critical value untuk sampel pada taraf signifikan $5 \%$ adalah 0,312 . Semua butir pertanyaan 1 sampai 8 adalah valid, karena nilai $r_{x y}>0,312$. Dengan demikian alat ukur yang digunakan dalam penelitian ini sesuai untuk mengukur tingkat kepuasan kerja pegawai. Hasil pengujian validitas kompensasi, Critical value untuk sampel pada taraf signifikan 5\% adalah 0,312. Hasil yang didapat menunjukkan bahwa semua butir pertanyaan 1 sampai 5 adalah valid, karena nilai $r_{x y}>0,312$. 
Dengan demikian alat ukur yang digunakan dalam penelitian ini sesuai untuk mengukur tingkat motivasi kerja. Hasil pengujian Validitas Motivasi kerja, Critical value untuk sampel pada taraf signifikan 5\% adalah 0,312. Hasil yang didapat menunjukkan bahwa semua butir pertanyaan 1 sampai 6 adalah valid, karena nilai $r_{x y}>0,312$. Dengan demikian alat ukur yang digunakan dalam penelitian ini sesuai untuk mengukur tingkat motivasi kerja. Hasil pengujian validitas karakteristik pekerjaan, Critical value untuk sampel pada taraf signifikan $5 \%$ adalah 0,312. Hasil menunjukkan bahwa semua butir pertanyaan 1 sampai 8 adalah valid, karena nilai $r_{x y}>0,312$. Dengan demikian alat ukur yang digunakan dalam penelitian ini sesuai untuk mengukur tingkat karakteristik pekerjaan.

Uji reliabilitas digunakan untuk mengetahui kehandalan suatu butir angket dalam penelitian. Dalam penelitian ini uji reliabilitas digunakan teknik Alpha Cronbach. Dari keempat variabel yang digunakan tersebut dapat disimpulkan mempunyai konsistensi yang tinggi karena keempat variabel tersebut mempunyai status reliabel karena mempunyai nilai cronbach alpha lebih besar dari 0,60.

Uji Asumsi Klasik. Hasil pengujian asumsi klasik sebagaimana telah disebutkan dalam metode yang digunakan pada penelitian ini. Uji normalitas dilakukan untuk mengetahui apakah variabel yang dianalisis memenuhi kriteria sebaran normal atau berdistribusi normal. Dengan membandingkan nilai p yang diperoleh dengan taraf signifikan 5\%, apabila nilai p> 0,05, maka data berdistribusi normal. Nilai probabilitas (p) menunjukkan angka sebesar 0,641 dengan taraf signifikan $(\alpha)$ 0,05. Dengan demikian data tersebut berdistribusi normal, karena $\mathrm{p}>\alpha$. Data yang terdistribusi normal merupakan prasyarat penggunaan statistik parametrik.

Berdasarkan uji multikolinieritas yang telah dilakukan dengan pengujian collinearity statistics. Hasil analisis multikolinearitas menunjukkan bahwa masing-masing variabel independen nilai $V I F>10$, dan nilai tolerance $<1$. Dengan demikian dapat disimpulkan bahwa model regresi tersebut tidak terdapat masalah multikolinearitas. Heteroskedastisitas adalah kondisi di mana sebaran atau varian variabel pengganggu $(\varepsilon)$ tidak konstan sepanjang observasi. 
Jika varians residual dari suatu pengamatan ke pengamatan yang lain tetap (konstan), maka disebut homoskedastisitas. Jika varians berbeda, disebut heteroskedastisitas. Untuk mendeteksi ada tidaknya heteroskedastisitas dapat dilakukan uji Glejser. Berdasarkan hasil uji heteroskedastisitas, penelitian ini tidak terjadi heteroskedastisitas karena p-value $>0,05$. Dengan demikian semua variabel independen memiliki varians yang konstan (sama) penyebarannya dan tidak mengalami masalah heteroskedastisitas.

Analisis ini digunakan dan dimaksudkan untuk mengetahui pengaruh dua atau lebih variabel independen terhadap variabel dependen. Dalam penelitian ini variabel independen yang meliputi: variabel motivasi, variabel pola kepemimpinan, dan variabel pengembangan karir diuji pengaruhnya terhadap variabel dependen yaitu variabel kinerja karyawan. Hasil analisis regresi berganda, maka dapat disusun model persamaan sebagai berikut:

$$
\mathrm{KK}=5,688+0,494(\mathrm{Kom})+0,292(\mathrm{Mot})+0,231 \text { (KrP). }
$$

Dari hasil analasis data yang telah dilakukan diperoleh bahwa F hitung adalah sebesar 19,136. Hasil uji uji F memperoleh nilai F-hitung sebesar 19,136 $>$ F-tabel $(2,92)$ dengan $p$-value sebesar 0,000 diterima pada taraf signifikasni $5 \%(\mathrm{p}<0,05)$. Dengan demikian model regresi yang menjelaskan pengaruh motivasi kerja, pola kepemimpinan, dan pengembangan karir terhadap kinerja karyawan adalah fit of goodness. Hasil analisis regresi berganda menunjukkan nilai $\mathrm{R}^{2}$ sebesar 0,615 . Hal ini menunjukkan bahwa $61,5 \%$ variasi dari kinerja karyawan dapat dijelaskan oleh variabel motivasi kerja, pola kepemimpinan, dan pengembangan karir, sedangkan sisanya sebesar 28,5 dijelaskan oleh variabel lain di luar model.

Pengujian secara individu ini untuk membuktikan bahwa koefisien regresi suatu model statistik itu signifikan atau tidak, maka dipakai uji t. Adapun hasil yang didapat kompensasi berpengaruh positif dan signifikan terhadap kepuasan kerja pegawai, motivasi kerja berpengaruh positif dan signifikan terhadap kepuasan kerja pegawai, dan karakteristik pekerjaan berpengaruh positif dan signifikan terhadap kepuasan kerja pegawai. 


\section{SIMPULAN}

Dari hasil pengujian hipotesis yang telah dilakukan dapat disimpulkan bahwa terdapat pengaruh positif yang signifikan dari pemberian kompensasi terhadap kepuasan kerja pegawai PT Jaya Metal Jakarta. Artinya semakin tinggi tingkat kompensasi yang diberikan maka semakin tinggi pula kepuasan kerja pegawai. Sebaliknya semakin rendah kompensasi, maka semakin rendah juga kepuasan kerja pegawai, artinya nilai probabilitas sebesar 0,000 diterima pada taraf signifikansi $5 \%(\mathrm{p}<0,05)$. Terdapat pengaruh positif yang signifikan dari motivasi kerja terhadap kepuasan kerja dengan nilai probabilitas sebesar 0,010 diterima pada taraf signifikansi $5 \%(\mathrm{p}<0,05)$. Artinya semakin tinggi tingkat motivasi kerja maka semakin tinggi pula kepuasan kerja pegawai. Sebaliknya semakin rendah motivasi kerja, maka semakin rendah juga kepuasan kerja pegawai. Terdapat pengaruh positif yang signifikan dari karakteristik pekerjaan terhadap kepuasan kerja pegawai dengan nilai probabilitas sebesar 0,031 diterima pada taraf signifikansi $5 \%(\mathrm{p}<0,05)$. Artinya semakin baik tingkat karakteristik pekerjaan, maka semakin baik pula kepuasan kerja pegawai. Sebaliknya semakin buruk karakteristik pekerjaan, maka semakin buruk juga tingkat kepuasan kerja pegawai.

Dalam penelitian ini terdapat beberapa keterbatasan penelitian yang perlu dipertimbangkan yang mungkin mempengaruhi hasil penelitian. Penelitian ini hanya menggunakan metode survei melalui kuesioner, sehingga kesimpulan yang diambil hanya berdasarkan data yang dikumpulkan melalui penggunaan instrumen secara tertulis. Penelitian ini hanya menggunakan 40 responden sebagai sampel, sehingga hasil penelitian tidak dapat di generalisasikan. Penelitian yang sama dengan jumlah populasi yang berbeda, maka hasilnya juga akan berbeda. Keterbatasan waktu, biaya, dan sumber daya manusia juga menjadi pembatas dalam menentukan jumlah sampel yang layak dalam suatu penelitian. Begitu juga tidak jarang menjadi kendala bagi peneliti untuk melakukan sesuatu yang ideal.

\section{PUSTAKA ACUAN}

Arep \& Tanjung. 2003. Manajemen Motivasi. Jakarta: Penerbit PT. Grasindo Luthans, F. 2006. Perilaku Organisasi, Edisi Sepuluh. Yogyakarta: Penerbit Andi. 
Anggara, D. 2007. Pengaruh Kepemimpinan, Motivasi, Pengawasan, dan Budaya Kerja Terhadap Kinerja Karyawan di CV. Rimba Sentosa Tawangsari Sukoharjo. (Skripsi tidak dipublikasikan). Surakarta: Fakultas Ekonomi. Universitas Muhammadiyah Surakarta.

Arikunto, S. 2006. Prosedur Penelitian: Suatu Pendekatan Praktek. Jakarta: Rineka Cipta.

Ghozali, I. 2006. Aplikasi Analisis Multivariate: Dengan Program SPSS. Semarang: Universitas Diponegoro.

Gorda, I.G.N. 2006. Manajemen Sumber Daya Manusia, cet. ketiga. Denpasar: Astabrata Bali.

Hani Handoko. 2001. Manajemen Personalia dan Sumber Daya Manusia. Yogyakarta: BPFE.

Hasibuan, SP, M. 2007. Manajemen Sumber Daya Manusia, Edisi Revisi. Cetakan kesepuluh. Jakarta: Bumi Aksara.

Kreitner, Robert \& K. Angelo. 2005. Perilaku Organisasi: Organizational Behavior. Jakarta: Salemba Empat.

Kuncoro, M. 2001. Metode Kuantitatif, Teori dan Aplikasi Untuk Bisnis Dan Ekonomi. Yogyakarta: UPP AMP-YKPN.

Kuncoro, M. 2003. Metode Riset Untuk Bisnis dan Ekonomi. Jakarta: Erlangga.

Kusriyanto, B. 1984. Meningkatkan Produktivitas Karyawan. Jakarta: PT.Gramedia.

Mathis, R.D. 2006. Manajemen Sumber Daya Manusia, 10th ed. Jakarta: Salemba Empat

Mangkunegara, A.P. 2007. Manajemen Sumber Daya Manusia Perusahaan. Bandung: PT Remaja Rosdakarya.

Mawar. 2007. Pengaruh Kompensasi, Pelatihan, Kepemimpinan, dan Lingkungan Kerja terhadap Kinerja Pegawai di PT.Askes ( Persero) Kantor Cabang Denpasar. (Tesis Tidak Dipublikasikan). Denpasar: Magister Manajemen Unversitas Udayana.

Rivai, V. 2004. Manajemen Sumber Daya Manusia untuk Perusahaan: Dari Teori ke Praktik. Jakarta: Raja Grafindo Persada.

Robbins S,P. 2006. Perilaku Organisasi. Edisi 10. Klaten : PT. Intan Sejati Klaten. 
Sedarmayanti. 2009. Sumber Daya Manusia dan Produktivitas Kerja, 3rd ed. Bandung: CV. Mandar Maju.

Schultz, D. P. \& Schultz, S. E. 2005. Theories of personality, 8th ed. Australia: Thomson Wadswarth.

Setiaji, B. 2006. Panduan Riset dengan Pendekatan Kuantitatif. Surakarta: Muhammadiyah Univesity Press.

Siagan, S.P. 2004. Manajemen Sumber Daya Manusia. Jakarta : BumiAksara.

Sugiyono. 2006. Statistika Untuk Penelitian. Bandung: Alfabeta.

Sutrisno, E. 2009. Manajemen Sumber Daya Manusia. Jakarta: Prenada Media Group.

Umar, H. 2007. Metode Penelitian untuk Skripsi dan Tesis Bisnis, edisi Baru. Jakarta : PT. Raja Grafindo Persada.

Winardi, J. 2004. Motivasi dan Pemotivasian Manajemen. Jakarta : PT. Raja Grafindo Persada.

Yulinda \& S.W. Harlyanti. 2009. Faktor-Faktor Yang Mempengaruhi Kepuasan Kerja Pegawai Pada Pegawai Dinas Luar Asuransi Jiwa Bersama Bumiputera 1912 Cabang Setiabudi Medan. Jurnal Manajemen Bisnis, Vol.2, No.1, Departemen Manajemen FE USU. 